\title{
3 A normative approach to transitions in energy demand
}

\author{
An energy justice and fuel poverty \\ case study
}

Kirsten E.H. Jenkins and Mari Martiskainen

\section{Introduction}

Meeting the emissions targets enshrined in the Paris Agreement will necessitate low-carbon, sustainability-oriented transitions across multiple sociotechnical domains, including electricity and heat, industry and buildings, and transport, to name a few. As acknowledged by a sociotechnical approach, this requires not only the rapid transformation of our physical energy systems, but of the societies that create and use them. Indeed, in the case of transitions in energy demand, it will influence who uses which energy source, how and when. Electrification is projected to influence patterns of mobility, changing the ways in which we drive and fuel our vehicles (see Bergman, Chapter 4; Bergman et al., 2017); the introduction of smart metering in the United Kingdom (UK) is enabling remote reading, with implications for user practice and social vulnerabilities, (see Jenkins et al., Chapter 6; Sovacool et al., 2017); and residential retrofit will alter the performance of our homes (see Brown et al., Chapter 7), for instance.

While these energy transitions are promised with the best in mind - often manifesting as a push towards low-carbon energy production forms and energy efficiency measures - it is inevitable that there will be winners and losers. Pertinently, this includes those unable to access or afford them. In this vein, making sure that all voices are represented in transitions plans and their actualisation is undoubtedly a question of social justice, equity and fairness.

As outlined by Jenkins et al. (2018, p. 67), failure to adequately engage with questions of justice throughout the transition process is dangerous given that it 'may lead to aggravated poverty, entrenched gender bias and non-participation as outcomes or by-products of "blinkered" decision-making'. Indeed, without a focus on justice, transitions may fail to acknowledge two sides of the debate surrounding energy demand: (1) the burdens of having too much energy or too many energy services, including subsequent waste, over-use and pollution, and (2) not having sufficient energy services, where some individuals lack access, are challenged by under-consumption and poverty, and may face health burdens and shortened lives as a consequence of restricted energy choices (Sovacool et al., 2016). Thus, our starting assertion is that justice is, and must be, central 
to transitions debates and planning, even in the context of demand reduction. This is not always the case, however.

Scholars and analysts frequently envision the process by which sustainability transitions take place to be one of disruptive change through transformative innovation (Markard et al., 2012; Schot and Steinmuller, 2016). As a result, proponents of transformative change suggest that by involving stakeholders from the outset, it can present more all-encompassing, robust solutions to sustainability challenges. For instance, Linnenluecke et al. (2017) identify that plans for transformational change recognise that environmental challenges present opportunities to meet the (currently unmet) needs of those at the 'bottom of the pyramid' - including the poorest of the poor (see also Bezboruah and Pillai, 2013; McAlpine et al., 2015; Tebo, 2005). Within the transitions literature, then, there appears an emerging concern for particular individuals who are seen to deserve more socially just outcomes.

Yet despite ongoing debates about ethics and justice across many fields of academic literature, one social element missing from transitions frameworks is explicit, practice-oriented engagement with the energy justice concept and related approaches to justice concerns (Jenkins et al., 2018); an omission that, arguably, is mirrored in practice. Indeed, beyond the walls of academia, and despite the broadening utilisation of the transitions concept, it is increasingly acknowledged that the 'socio-' or social element is frequently missing in the transitions literature and transition plans, including failures to recognise their social justice and equity implications (see Goldthau and Sovacool, 2012; Jamieson, 2014; Markowitz and Shari, 2012; Newell and Mulvaney, 2013; Sovacool et al., 2016; Swilling and Annecke, 2012).

As an illustration, the 2009 UK government's Low Carbon Transition Plan (DECC, 2009) (the last document of its type) includes only passing reference to justice concepts as it mentions 'fairness', which is characterised as the fair distribution of costs only without attention to wider aspects of accessibility, fairness in the decision-making process, or the inclusion of all stakeholders and users. ${ }^{1}$ For this reason, Eames and Hunt (2013, p. 58) note that even 'a 'low-carbon' transition has the potential to distribute its costs and benefits just as unequally [as historical fossil-based transitions] without governance mindful of distributional justice' or, as is argued throughout, issues of justice as recognition and procedural justice too.

This chapter serves a dual purpose. First, it reiterates and reaffirms the need for socially just transitions approaches in energy demand scholarship and explores the role of the three-tenet energy justice framework in this. In so doing, it introduces a potentially new audience to energy justice scholarship. Second, through a case study of fuel poverty, it begins to explore both the dangers of failing to acknowledge justice outcomes and, conversely, what doing so may practically look like. We close with policy-relevant recommendations towards the integration of energy justice thinking in demand reduction efforts. 


\section{Normative approaches to transitions in demand}

Arguably, there are (at least) two weaknesses in our attempts to understanding the normativity of energy demand challenges to date. First, a large proportion of the research on normative approaches to energy demand - that relating to how things should or ought to be - is conducted from an individual's perspective, considering personal normativity and moral choice. As we aim to reduce energy demand, this is a clear advantage. Yet while they capture some concerns of normativity, they do not allow an understanding of how such normative approaches might be embedded in and emerge from transitions in energy demand. Further, individuals may find it difficult to change as they are locked into unsustainable infrastructure, including living in sub-standard housing stock or working on the minimum wage, thereby confining choice. Moreover, with these limitations in mind, a focus on individuals does not provide opportunities for the forms of systematic change we require. ${ }^{2}$ For that, we need a broader outlook.

As a second weakness is that we, as scholars, have yet to agree on who we are concerned about. A large proportion of justice scholarship in the energy demand domain focuses on vulnerable consumers - those 'left behind' without regular or affordable access to energy, and this can vary considerably depending on context. Indeed, a range of work has emerged that considers particular vulnerable groups including the elderly or the unwell (Thomson et al., 2017a), those living in adverse housing conditions (Healy and Clinch, 2004), or individuals living with disabilities (Snell et al., 2015).

Yet work by Chatterton et al. (2016) shows that there are in fact only a few (typically well off) minority groups that place the greatest burden on energy networks due to their high energy consumption. ${ }^{3}$ Therefore, they argue that we should target the less vulnerable in order to make meaningful progress with demand reduction. As an illustration, they state that

in order to make these reductions, rather than assuming a need for an 80 reduction across all of society, it makes sense to at least examine the potential for reducing consumption in that sector of society that is consuming greater than 30\% more energy per household than the average.

(Chatterton et al., 2016, p. 87)

In this case then, the measures needed to reach each group would trade off. Indeed, these different approaches raise contrasting normative questions around who we should engage with, how and to what end.

While any one approach is inevitably limited in its ability to resolve a problem entirely - especially one as large and complex as injustice - the remainder of this chapter positions the energy justice framework as one way of further considering and potentially overcoming these challenges above challenges.

In line with the sociotechnical approach, the energy justice framework is one that forcefully reminds us that energy dilemmas are about more than merely hardware (Sovacool and Dworkin, 2015). The concept has emerged amid the 
realisation that our energy structures require widespread reform, and out of a growing interest in the justice implications of energy consumption and energy's societal impacts (Hall, 2013). Against the background of the environmental and climate justice literatures, and in light of this surrounding context, energy justice thus aims 'to provide all individuals, across all areas, with safe, affordable and sustainable energy' (McCauley et al., 2013, p. 1).

As part of its growing popularity, energy justice is increasingly characterised as an analytical tool - one that, for Heffron et al. (2015), can achieve a just balance in the energy trilemma, which they typify as economics (energy finance), the environment (climate change mitigation) and politics (energy security). As one example, Heffron et al. (2015, p. 172) develop an energy justice metric, which is designed to connect with economists through quantitative analysis of energy justice, allowing it to be evaluated in monetary terms. This approach produces three results: (1) an individual-country energy justice metric and (2) an energy justice metric for each type of energy generation source, e.g. nuclear power, both of which allow (3) the cost of energy justice to then be factored in to an economic model calculation in the form of a cost-benefit analysis. Sovacool and Dworkin (2015, p. 436) state in relation to such models, that energy justice thus 'presents a useful decision-making tool that can assist energy planners and consumers in making more informed energy choices' as well as serving as 'an important analytical tool for energy researchers striving to understand how values get built into energy systems or to resolve common energy problems'. In this regard, the energy justice concept shares some commonalities with the political reach of the transitions concept and sociotechnical approach more broadly.

\section{The energy justice tenet framework}

A range of tenet frameworks have emerged within the energy justice field. McCauley et al. (2013) use three - distributional justice, procedural justice and justice as recognition - whereas others dismiss the inclusion of recognition as a tenet, including Sidortsov and Sovacool (2015) who instead focus on distributional justice, procedural justice and cosmopolitanism as core concepts. In addition, Heffron and McCauley (2017) consider restorative justice and Sovacool et al. (2016) add the eight concerns of availability, affordability, due process, intragenerational equity, intergenerational equity, sustainability, transparency and accountability, and responsibility. In keeping with McCauley et al. (2013), however, this chapter utilises the framework of three core tenets, distributional justice, procedural justice and justice as recognition, including justice as recognition as the third tenet based on the works of Fraser (2014).

In a change from the norm, the order in which the tenets are typically used distribution, procedure, recognition - is altered and, instead, justice as recognition is in second place. This leaves the structure of distributional justice, justice as recognition and procedural justice. This approach builds upon the work of Jenkins et al. (2016) who argue for a reordering of the tenets on the logic that if injustice is to be tackled, you must (a) identify the concern - distribution, 
(b) identify who it affects - recognition, and only then (c) identify strategies for remediation - procedure. This is, in effect, a 'what, who and how' approach to tackling energy justice concerns, with the intention that energy justice can exist as a solution-based framework that not only characterises injustices but can also help tackle them. To this end, the following paragraphs not only introduce the conceptual background to these tenets, but also provide real-world case studies of their meaning in practice.

\section{Distributional justice: fuel poverty in the UK and beyond}

The first tenet of energy justice is distributional justice. Energy justice is an inherently spatial concept that includes both the physically unequal allocation of environmental benefits and ills and the uneven distribution of their associated responsibilities (Walker, 2009, p. 615): for example, exposure to risk. Thus, energy justice can appear as a situation where 'questions about the desirability of technologies in principle become entangled with issues that relate to specific localities' (Owens and Driffill, 2008, p. 4414), and represents a call for the distribution of benefits and ills on all members of society regardless of income, race etc. (Bullard, 2005; Heffron et al., 2015). To illustrate the application of distributional justice, we move here to the illustrative example of fuel poverty both in the UK and briefly, beyond.

In consumption terms, distributional justice is typically discussed in relation to the issues of affordability, availability and sustainability (Sovacool and Dworkin, 2015). This explains the ready application of energy justice literature to the issue of fuel poverty (see Fuller and McCauley, 2016; McCauley et al., 2013; Sovacool, 2015; Walker and Day, 2012), which was originally defined as having to spend more than 10 per cent of a households' income on energy bills (Boardman, 1991). Distributional justice in this early scenario reflected a concern for the unequal allocation of energy resources and the sometimesprohibitive costs of them. Yet while the 10 per cent definition was useful (and indeed, is still a widely used indicator in many countries) it was deemed by many to be too rigid to enable for all the complexities linked to fuel poverty to be taken into account (Thomson et al., 2017b).

Throughout the history of the fuel poverty concept, then, the 10 per cent definition has been further divided into three main causes: (1) living in an energy-inefficient home, (2) having a low income and (3) facing high energy bills. Indeed, fuel poverty, or energy poverty, ${ }^{4}$ has evolved to become a concern for the inability to 'attain a socially and materially necessitated level of domestic energy services' (Bouzarovski and Petrova, 2015, p. 31) - a wider definition than a simple proportion of income that considers the intersections between a home, its occupants and the energy system, all of which will vary depending on cultural and contextual factors. Nonetheless, despite this broadening context, what is being discussed here is what energy resources we do or do not have access to a manifestation of energy outcomes that distributional justice can reveal and help us to understand. 
To clarify, given that distributional justice is concerned with the distribution of goods and services across society, it follows that fuel poverty is a clear example; the majority of individuals enjoy better access to energy services than a minority few and the resultant injustices across social groups (e.g. according to their housing type or geography) leaves some groups more vulnerable than others. This is, first and foremost, a failure of not only energy policy, but also policies on housing, social issues and welfare standards. Second, it is something that we have to account for as we consider not only how to alleviate fuel poverty equitably, but how energy demand policy may further compound or enable this (Gillard et al., 2017).

The reported incidence rates of fuel poverty are high. In England, 11.1 per cent of the population were thought to be in fuel poverty in 2016, a figure that corresponds to approximately 2.55 million households (BEIS, 2018). This is despite positive progress towards the interim 2020 fuel poverty target, which presents a legal obligation for as many fuel poor homes as 'reasonably practicable' to be raised to Band $\mathrm{E}$ in the first instance, with Band $\mathrm{C}$ as the $2030 \mathrm{goal}^{5}$ (White et al., 2014). Rates in Scotland, Wales and Northern Ireland are even more concerning. In 2016, 26.5 per cent of the total Scottish population, or 649,000 homes, were deemed fuel pool and of those, 183,000 were extremely fuel poor (Scottish Government, 2018). The latest figures for Northern Ireland are 42 per cent and for Wales 23 per cent of households living in fuel poverty ${ }^{6}$ (Department for Communities, 2018; Welsh Government, 2018). In this regard, distributional inequities are rife.

While numerous advocates have stated that improving energy efficiency and reducing demand can reduce fuel poverty (e.g. Sorrell, 2015), we must be careful of two caveats: first, that fuel poverty is not experienced the same way everywhere and second, that it can go beyond simple maldistribution.

The UK's framing of fuel poverty has been influential in other developed economies, including researchers in New Zealand (Day et al., 2016; HowdenChapman et al., 2012; O'Sullivan et al., 2012; Viggers et al., 2013) and Europe, where concerns have appeared around a household's ability to heat their home, manifestations of damp and mould and energy bill debts (Day et al., 2016; Healy and Clinch, 2004; Thomson and Snell, 2013), and increasingly overheating. For example, a recent European-funded initiative - EU Energy Poverty Observatory $($ EPOV $)$ - brings together researchers, academics, policymakers and practitioners across the EU, aiming to understand and address energy poverty in Europe in a more coherent way. EPOV seeks to illustrate, that (a) our assets are not distributed equally and (b) that through this maldistribution, issues of inequity emerge. It follows that when planning to overhaul energy infrastructure for low-carbon goals, we should also anticipate and mitigate the potential impacts of our choices with a view to reducing unequal burdens across a wide range of contexts, including attention to the potential externalisation of UK energy policy 'ills'.

Second, access cannot always be evenly distributed, at least not without major grid infrastructural changes. Access to ground source heat pumps or localised district heating systems that may lower localised energy costs is restricted, 
for instance, and although we use an old reference, some island communities in the UK still do not have mains gas supply for heating (Barbour and Twidell, 1981). Thus, Walker and Bulkeley (2006) and Eames and Hunt (2013) note that unequal distribution is not always unjust. Instead, it is often the 'fairness' of the processes surrounding infrastructural development that is important (Walker and Bulkeley, 2006, p. 4), and as such claims for distributional justice require that evidence of inequality are combined with an argument for fair treatment (Eames and Hunt, 2013). Throughout this chapter such arguments are taken to manifest as calls for justice as recognition and procedural justice too.

\section{Justice as recognition}

Justice as recognition is taken to be a means of engaging with the questions of 'who' is energy justice for, and, importantly, who is responsible for its provision. It appears as a concern for "how people are involved in environmental decisionmaking, or "who (and what) is given respect"' (Eames, 2011). Drawing on Fraser (1999), Schlosberg (2007, p. 18) conceptualises the concerns around justice as recognition as three separate issues: (1) practices of cultural domination, (2) patterns of non-recognition (invisibility of individuals and their concerns), and (3) disrespect through stereotyping and disparaging language: misrecognition. Within this context, justice as recognition is more than tolerance, and requires that individuals must be fairly represented, that they must be free from physical threats, and that they must be offered complete and equal political rights (Schlosberg, 2003).

The process of cultural domination may include, as one of innumerate potential examples, 'the process of disrespect, insult and degradation that devalue some individuals and some places' identities in comparison to others' (Walker 2009 , p. 615). In this context, justice as recognition calls for the respect of difference, and a move to prevent one group dominating others (Martin et al., 2013). Further, justice recognition also represents a call to acknowledge diversity within and between environmental justice movements (Hall et al., 2013). Thus, it includes calls to recognise the divergent perspectives of different ethnic, racial and gender differences (Fraser, 1999). Justice as recognition also appears as non-recognition, the invisibility of individuals and their concerns, as exemplified by the often-cited issue of fuel poverty. Finally, concerns may also arise not over a failure to recognise, but as misrecognising, a distortion of individual's views that may appear demeaning or contemptible (Schlosberg, 2003).

Fuel poverty has been shown to affect a household's health, wellbeing and quality of life. For example, living in a cold home has been linked to weight gain in babies and young children, while damp and mouldy homes can cause breathing problems and respiratory illnesses such as asthma (Guertler and Royston, 2013). The lack of heating and insulation can mean that those facing fuel poverty often live in very cold homes, being only able to heat certain parts, or room/s, which limits their use. It is also likely that with warming temperatures, overheating and being able to cool a home will become concerns too. 
For those living in fuel poverty, their home becomes a place of discomfort, ill health and even death. In this respect, the health impacts of fuel poverty are very significant. It is estimated that each year, the English National Health Service (NHS) faces a bill of $£ 1.36$ billion for treating illnesses linked to fuel poverty (Public Health England, 2014). Mental health problems, respiratory problems like asthma and circulatory illnesses such as heart disease have been linked to cold and damp homes (Marmot Review Team, 2011). Indeed, as perplexing as it sounds, in a country of seemingly high development status, individuals die each year due to cold homes (Jolin, 2014). Fuel poverty can also have an impact on children's education. Living in a cold home can make completing homework difficult and illnesses due to cold and damp homes mean children have to take more time off school (Guertler and Royston, 2013). This comes as acknowledgement that different individuals can experience vulnerability to fuel poverty in different ways, depending on their personal circumstances (Middlemiss and Gillard, 2015).

In his exploration of affordable warmth and justice, Sovacool (2015) highlights concern for a particular group in society - those unable to access affordable heat, who often become visible through the effects listed above. Yet Walker and Day (2012, p. 71) state that fuel poverty 'can be read as a lack of recognition of the needs to certain groups, and, more fundamentally, as a lack of equal respect accorded to their wellbeing'. We seek to highlight here that fuel poverty is both visible and invisible and that one of the largest challenges is establishing who is being affected. Indeed, while identifying those who face fuel poverty is key towards recognising the problem and addressing it, it is not always easy to identify those who are suffering. Often, there is stigma attached to being fuel poor (Hards, 2013), so much so that households avoid seeking help for fear of being seen not being able to cope with certain aspects of their life. Furthermore, there are also those who may not realise that they are in fact living in fuel poverty, a factor that has recently been recognised by the 'Being Warm Being Happy' (2017) research project, which examines fuel poverty among adults with learning disabilities.

Beyond specific social groups that are statistically more likely to be affected, England's leading fuel poverty charity National Energy Action (NEA) identifies that fuel poverty can occur for anyone (NEA, 2017). Previous research has recognised that those considered vulnerable groups, i.e. children, the elderly and individuals with disabilities or long-term health conditions, can be especially susceptible to the impacts of fuel poverty (Public Health England, 2014). However, fuel poverty often becomes an issue at a time of crisis, when an individual's circumstances change dramatically and they become unable to 'function according to the dominant expectations of present-day energy markets' (Martiskainen et al., 2018, p. 29). In this regard, Sovacool (2015) outlines that the issue of fuel poverty intersects with procedural justice, as affected households have neither the time nor the means to participate in energy decisionmaking that may rectify injustices.

As we move towards policy for reducing fuel poverty and for reducing energy demand, it becomes paramount to both understand the links between the two 


\section{Kirsten E.H. Jenkins and Mari Martiskainen}

and to gain a more nuanced recognition of energy needs and their link to vulnerability within particular groups (Gillard et al., 2017); a justice as recognition concern. This includes ongoing reflexivity around who is being negatively impacted by policy choices and who is responsible for those outcomes. In this context, Gillard et al. (2017, p. 55) identify that 'a recognition-based approach can help to identify the particulars of energy injustice for different groups and strengthen the political response'.

\section{Procedural justice}

The last tenet in the reordered tenet framework is procedural justice, or the 'how' of energy justice. Procedural justice concerns access to decision-making processes that govern the distributions outlined above, and manifests as a call for equitable procedures that engage all stakeholders in a non-discriminatory way (Bullard, 2005; Walker, 2009). It states that all groups should be able to participate in decision-making, and that their contributions should be taken seriously throughout. It also requires participation, impartiality and full information disclosure by government and industry (Davies, 2006), and the use of appropriate and sympathetic engagement mechanisms (Todd and Zografos, 2005). It is concerned, then, about the fairness of decision-making processes, or justice in 'doing', and emerges as a claim for representational space and free speech (Sayer, 2011; Sze and London, 2008). For Walker (2012) these requirements can be split in to four key rights:

1 access to information, what type of information and who it is provided by;

2 access to and meaningful participation in decision-making;

3 lack of bias on the part of decision-makers;

4 access to legal processes for achieving redress.

Procedural justice manifestations include, as an illustration, questions arising around how and for whom community renewables projects are developed (Walker and Devine-Wright, 2008), and the ethics of the emergent voluntarism debate, where communities volunteer to host facilities (Butler and Simmons, 2013).

Several programmes provided by the UK government, non-governmental organisations (NGOs) and charitable organisations have addressed fuel poverty over the years (see for example Rosenow et al., 2013; Sovacool, 2015). Addressing fuel poverty has been, for example, one of key drivers for building-related energy efficiency policies (Kern et al., 2017). However, despite all the efforts and government pledges to eradicate fuel poverty, it still exists widely in the UK and the number of fuel poor households has been rather stable in recent years.

The government's rhetoric outlined in 2001 was to end the problem of fuel poverty for vulnerable households by 2010. In 2002, this was clarified to reflect the goal of ending fuel poverty for vulnerable and non-vulnerable households living in social housing by 2010. Fuel poverty in other households was to be 
targeted after progress in these groups, with a target that by November 2016, English citizens should not be living in fuel poverty (DEFRA, 2003). This has changed to instead improving a reasonable proportion of fuel poor housing. In 2015, the UK government published a Fuel Poverty Strategy (DECC, 2015) for the first time in 14 years. This set out a new target for England: 'The fuel poverty target is to ensure that as many fuel poor homes as is reasonably practicable achieve a minimum energy efficiency rating of Band C, by 2030' (DECC, 2015, p. 12). This change in rhetoric was also coupled with the reduction in the number of households that had received energy efficiency measures under the various government schemes (for detailed analysis on UK policy mix changes, see Kern et al., 2017).

Fuel poverty is not an easy problem to solve. As fuel poverty has causes and implications that go beyond energy, addressing it will also require considering issues beyond energy policy (e.g. housing, social and health policy). Recently, scholars in the field of energy research have highlighted that fuel poverty needs to be rethought as a complex issue (e.g. Baker et al., 2018) However, there is a danger that those facing fuel poverty are still rather invisible in the quarters where energy, or social, policy decisions are made. Furthermore, as Sovacool (2015) has highlighted, households affected by fuel poverty may not have the time nor the means to participate in energy policy decision-making. As Gillard et al. (2017) identify, this can be either through a lack of capability, or a lack of trust. While there are several charitable organisations and community initiatives - such as Energy Cafés, which provide locally-targeted advice for those facing fuel poverty (see Martiskainen et al., 2018), these are often limited in scope, stop-start in nature and have to rely on external support and volunteer effort. The lack of sufficient government effort to get to the root of the problem indicates how those living in fuel poverty in the UK have become the invisible, yet accepted, losers in the UK's energy system.

\section{Conclusions and policy recommendations: towards just energy transitions}

As a result of our reflections, this section makes both conceptual and empirically founded conclusions and policy recommendations. First, as a larger conceptual claim and in line with previous work (Jenkins et al., 2018), we present the argument that it is within the overarching process of sociotechnical change that issues of energy justice emerge, where inattention to social justice issues can cause injustices, or via their inclusion can provide a means to solve them. Thus, we argue for greater engagement with the energy justice approach in both academia and in practice, where it can be used as a means to guide ethically sound decision-making. This comes partly as acknowledgement that social science perspectives on energy transitions are under-represented in academic scholarship (Guy and Shove, 2000; Sovacool, 2015; Wilhite et al., 2000) and, that where they do exist, the economic and geopolitical aspects of energy take precedence (Edberg and Tarasova, 2016). 


\section{Kirsten E.H. Jenkins and Mari Martiskainen}

As an illustration of why this is necessary in the context of energy demand, we have sought to highlight both the dangers of failing to appreciate justice outcomes and the factors that doing so may reveal, from patterns of poor housing infrastructure to vulnerable groups, inadequate processes, and even affluent parties who, through a process of redistribution may not only lower fuel poverty rates, but also decrease energy demand in the process. The target here is not only to make sure that demand processes are sustainable but, as a fundamental part of that, that they are fair.

We have highlighted that fuel poverty is an urgent issue that needs to be addressed as an energy, social and health issue, and at all levels of government, local authorities and health authorities. In this context, it is possible to give a series of case-specific, policy-relevant recommendations that illustrate the potential mobilisation of energy justice approaches. We base these both on our own analysis, and as a synthesis of recommendations based across relevant academic literature.

First, we identify that government and businesses must identify those who may be vulnerable and then both ascertain and make provision for vulnerable customers through targeted subsidies, exemptions and efficiency measures. This recommendation has bearing on energy efficiency policy in particular, where questions are raised about the equity and design of its implementation. In this context, justice principles can provide guidelines for policy interventions by ensuring that energy efficiency schemes reach households in a way that meets their specific needs (Gillard et al., 2017).

Second, as acknowledgement that fuel poverty goes beyond simple affordability to an outcome of living in an inefficient home, we require strong and consistent policies to upgrade the national housing stock (see also Chapter 7), combined with consumer engagement programmes to enable participatory justice throughout this process. At the same time, we must be careful not to reinforce structural or social inequalities e.g. through stereotyping recruitment practices (Gillard et al., 2017).

Third, in terms of achieving procedural justice, funded Energy Cafés can act as a triage service, bringing together local authorities, health workers, community organisations and individuals in a trusted setting, providing advice and ensuring that energy needs are met (Martiskainen et al., 2018). This becomes especially important when you consider that the more individuals that are successfully engaged and take on energy efficiency schemes, the greater the potential success of transition pathways. These and similar ventures require grant funding in order to provide a continued service, train fuel poverty advisors and transfer learning to others.

Fourth, we must acknowledge the impact of energy pricing and subsidies and their knock-on effects especially on low income and other potentially vulnerable or low-income consumers (see Chapter 6 on smart metering, as an example). This comes as acknowledgement that despite some positive policy measures (including the English Warm Front Scheme which was partially merged into the Energy Company Obligation), increasing prices for electricity 
and natural gas have rapidly increased compared to incomes, thereby mitigating some positive effects (Sovacool, 2015). In this regard, we need socially justice energy policy mixes (see Chapter 12).

Through these measures and others in the domain of energy demand, we have the potential to both acknowledge and embed normativity in energy demand reduction efforts.

\section{Acknowledgements}

This chapter borrows from, and significantly extends the arguments initially presented in, 'Humanizing sociotechnical transitions through energy justice: An ethical framework for global transformative change', published in Energy Policy 117 (June 2018), pp. 66-74.

\section{Notes}

1 Rawls (1985) describes that 'justice' can be divided into the principles of liberty and equality, with a further subdivision of the latter including the principle of 'fair equality of opportunity'. In this regard, they can be seen as fundamentally interlinked concepts.

2 Unless, of course, they are persuasive on a large scale, though there is limited evidence of this level of effectivity to date.

3 See Chatterton et al. (2016) for an exploration of who 'high consumers' may be considered as in the UK context, including the 'energy decadent', where individual circumstances allow high consumption through choice.

4 We acknowledge here that there is a muddied history around 'fuel' and 'energy' poverty distinctions. In line with Bouzarovski and Petrova (2015, p. 33), we present the case that both can be considered under the same umbrella - 'a set of domestic energy circumstances that do not allow for participating in the lifestyles, customs and activities that define membership of society'. This definition arises despite the fact that energy poverty arguably has a tradition in developing world electrification and fuel poverty in developed world originated as a concern for unaffordable warmth within the home.

5 An Energy Performance Certificate (or EPC) is required for properties when constructed, sold or let. The EPC provides details on the energy performance of the property and what you can do to improve it. It is banded between A (the highest) and G (the lowest).

6 Note that different indicators are used in England, and Scotland, Wales and Northern Ireland for measuring fuel poverty. England uses a 'low income high costs' indicator, which states that a household is in fuel poverty if their fuel bills are above national average and, were they to pay those costs, their residual income would be below the official poverty line. Scotland, Wales and Northern Ireland use the 10 per cent of indicator, i.e. a household is in fuel poverty if they have to spend more than 10 per cent of their income on fuel bills.

\section{References}

Baker, K., Mould, R. and Restrick, S. (2018) Rethink fuel poverty as a complex problem, Nature Energy 3: 610-612 .

Barbour, D. and Twidell, J. (1981) Energy use on the island of North Ronaldsay, Orkney. Energy for Rural and Island Communities: 39-51. 
Being Warm Being Happy (2017) Being Warm Being Happy Homepage. Available online at: https://beingwarmbeinghappy.org/.

BEIS (2018) Annual Fuel Poverty Statistics Report (2016 data). Department for Business, Energy and Industrial Strategy, London, UK.

Bergmans, N., Schwanen, T. and Sovacool, B.K. (2017) Imagined people, behaviour and future mobility: Insights from visions of electric vehicles and car clubs in the United Kingdom. Transport Policy 59: 165-173.

Bezboruah, K.C. and Pillai, V. (2013) Assessing the participation of women in microfinance institutions: evidence from a multinational study. Journal of Social Service Research 39(5): 616-628.

Boardman, B. (1991) Fixing Fuel Poverty: Challenges and Solutions. Belhaven Press, London, UK.

Bouzarovski, S. and Petrova, S. (2015) A global perspective on domestic energy deprivation: Overcoming the energy poverty-fuel poverty binary. Energy Research and Social Science 10: 31-40. DOI: 10.1016/j.erss.2015.06.007.

Bullard, R.D. (2005) Environmental Justice in the 21st Century. In: Dryzek, J. and Schlosberg, D. (Eds) Debating the Earth. Oxford University Press, Oxford, UK.

Butler, C. and Simmons, P. (2013) Framing Energy Justice in the UK: The Nuclear Case. In: Bickerstaff, K., Walker, G. and Bulkeley, H. (Eds) Energy Justice in a Changing Climate: Social Equity and Low-carbon Energy. Zed Books, London, UK.

Chatterton, T.J., Anable, J., Barnes, J. and Yeboah, G. (2016) Mapping household direct energy consumption in the United Kingdom to provide a new perspective on energy justice. Energy Research and Social Science 18: 71-87.

Davies, A. (2006) Environmental justice as subtext or omission: Examining discourses of anti-incineration campaigns in Ireland. Geoforum 37: 708-724.

Day, R., Walker, G. and Simcock, N. (2016) Conceptualising energy use and energy poverty using a capabilities framework. Energy Policy 93: 255-264.

DECC (2009) The UK Low Carbon Transition Plan: National Strategy for Climate and Energy. Department of Energy and Climate Change, London, UK.

DECC (2015) Cutting the Cost of Keeping Warm - A Fuel Poverty Strategy for England. March 2015. HM Government, London, UK.

DEFRA (Department of Environment, Food and Rural Affairs) (2003) The UK Fuel Poverty Strategy: 1st Annual Progress Report. HM Government, London, UK.

Department for Communications (2018) Fuel Poverty. Available at: www.communitiesni.gov.uk/topics/housing/fuel-poverty.

Eames, M. (2011) Energy, innovation, equity and justice. Energy justice in a changing climate: Defining an agenda. InCluESEV Conference, London

Eames, M. and Hunt, M. (2013) Energy Justice in Sustainability Transitions Research. In: Bickerstaff, K., Walker, G. and Bulkeley, H. (Eds) Energy Justice in a Changing Climate: Social Equity and Low-Carbon Energy. Zed Books, London, UK.

Edberg, K. and Tarasova, E. (2016) Phasing out of phasing in: Framing the role of nuclear power in the Swedish energy transition. Energy Research and Social Science 13: 170-179.

Fraser, N. (1999) Social Justice in the Age of Identity Politics. In: Henderson, G. and Waterstone, M. (Eds) Geographical Thought: A Praxis Perspective. Routledge, Oxford, UK.

Fraser, N. (2014) Justice Interrupts. Routledge, London, UK.

Fuller, S. and McCauley, D. (2016) Framing energy justice: Perspectives from activism and advocacy. Energy Research and Social Science 11: 1-8. 
Gillard, R., Snell, C. and Bevan, M. (2017) Advancing an energy justice perspective on fuel poverty: Household vulnerability and domestic retrofit policy in the United Kingdom. Energy Research and Social Science 29: 53-61.

Goldthau, A. and Sovacool, K.B. (2012) The uniqueness of the energy security, justice, and governance problem. Energy Policy 41: 232-240.

Guertler, P. and Royston, S. (2013) Fact-file: Families and Fuel Poverty. Association for the Conservation of Energy, London, UK. Available at: www.ukace.org/wp-content/ uploads/2013/02/ACE-and-EBR-fact-file-2012-02-Families-and-fuel-poverty-pdf.

Guy, S. and Shove, E. (2000) A Sociology of Energy, Buildings and the Environment: Constructing Knowledge, Designing Practice. Oxford, Routledge, UK.

Hall, S.M. (2013) Energy justice and ethical consumption: Comparison, synthesis and lesson drawing. Local Environment 18(4): 422-437.

Hall, M.S., Hards, S. and Bulkeley, H. (2013) New approaches to energy: Equity, justice and vulnerability: An introduction to the special issue. Local Environment: The International Journal of Justice and Sustainability 18(4): 413-421.

Hards, S.K. (2013) Status, stigma and energy practices in the home, Local Environment 18(4): 438-454.

Healy, J.D. and Clinch, J.P. (2004) Quantifying the severity of fuel poverty, its relationship with poor housing and reasons for non-investment in energy-saving measures in Ireland. Energy Policy 32(2): 207-220.

Heffron, R.J. and McCauley, D. (2017) The concept of energy justice across the disciplines. Energy Policy 105: 658-667.

Heffron, R.J., McCauley, D. and Sovacool, B.K. (2015) Resolving society's energy trilemma through the Energy Justice Metric. Energy Policy 87: 168-176.

Howden-Chapman, P., Viggers, H., Chapman, R., O'Sullivan, K., Barnard, L.T. and Lloyd, B. (2012) Tackling cold housing and fuel poverty in New Zealand: A review of policies, research, and health impacts. Energy Policy 49: 134-142.

Jamieson, D. (2014) Reason in a Dark Time: Why the Struggle against Climate Change Failed - and What it Means for Our Future. Oxford University Press, Oxford, UK.

Jenkins, K., McCauley, D., Heffron, R., Stephan, H. and Rehner, R. (2016) Energy justice: A conceptual review. Energy Research and Social Science 11: 174-182.

Jenkins, K., Sovacool, B.K. and McCauley, D. (2018) Humanizing sociotechnical transitions through energy justice: An ethical framework for global transformative change. Energy Policy 117: 66-74.

Jolin, L. (2014) The scandal of Britain's fuel poverty deaths. Guardian. 11 September 2014. Available at: www.theguardian.com/big-energy-debate/2014/sep/11/fuel-povertyscandal-winter-deaths.

Kern, F., Kivimaa, P. and Martiskainen, M. (2017) Policy packaging or policy patching? The development of complex energy efficiency policy mixes. Energy Research and Social Science 23: 11-25. DOI: 10.1016/j.erss.2016.11.002.

Liddell, C. and Morris, C. (2010) Fuel poverty and human health: A review of recent evidence. Energy Policy 38: 2987-2997.

Linnenluecke, M.K., Verreynne, M., de Villiers Scheepers, M.J. and Venter, C. (2017) A review of collaborative planning approaches for transformative change towards a sustainable future. Journal of Cleaner Production 124(4): 3212-3224.

Markard, J., Raven, R. and Truffer, B. (2012) Sustainability transitions: An emerging field of research and its prospects. Research Policy 41(6): 955-967.

Markowitz, E.M. and Shari, A.F. (2012) Climate change and moral judgment. Nature Climate Change 2: 243-247. 
Marmot Review Team (2011) The Health Impacts of Cold Homes and Fuel Poverty. Written by the Marmot Review Team for Friends of the Earth. University College London, London, UK. Available at: https://friendsoftheearth.uk/sites/default/files/ downloads/cold_homes_health.pdf.

Martin, A., Gross-Camp, N., Kebede, B., McGuire, S. and Munyarukaza, J. (2013) Whose environmental justice? Exploring local and global perspectives in a payments for ecosystems services scheme in Rwanda. Geoforum 54: 167-177.

Martiskainen, M., Heiskanen, E. and Speciale, G. (2018) Community energy initiatives to alleviate fuel poverty: the material politics of Energy Cafés. Local Environment 23(1): 20-35.

McAlpine, C.A., Seabrook, L.M., Ryan, J.G., Feeney, B.J., Ripple, W.J., Ehrlich, A.H. and Ehrlich, P.R. (2015) Transformational change: Creating a safe operating space for humanity. Ecology and Society 20(1): 56-61.

McCauley, D., Heffron, R., Stephan, H. and Jenkins, K. (2013) Advancing energy justice: The triumvirate of tenets. International Energy Law Review 32(3): 107-110.

Middlemiss, L. and Gillard, R. (2015) Fuel poverty from the bottom-up: Characterising household energy vulnerability through the lived experience of the fuel poor. Energy Research and Social Science 6: 146-154.

NEA (2017) UK Fuel Poverty Monitor 2016-2017. A review of progress across the nations. National Energy Action (NEA) and Energy Action Scotland (EAS). Available at: www.nea.org.uk/wp-content/uploads/2016/05/FPM_2016_low_res.pdf.

Newell, P. and Mulvaney, D. (2013) The political economy of the 'just transition'. The Geographical Journal 179(2): 132-140.

Owens, S. and Driffill, L. (2008) How to change attitudes and behaviours in the context of energy. Energy Policy 36(12): 4412-4418.

O'Sullivan, K., Howden-Chapman, P. and Fougere, G. (2012) Death by disconnection: The missing public health voice in newspaper coverage of a fuel poverty-related death. K tuitui: the New Zealand Journal of Social Sciences 7: 51-60.

Pereira, R., Barbosa, S. and Carvalho, F.P. (2014) Uranium mining in Portugal: A review of the environmental legacies of the largest mines and environmental and human health impacts. Environmental Geochemistry and Heath 36(2): 285-301.

Public Health England (2014) Fuel Poverty and Cold Home-related Health Problems. Health equity briefing 7. September 2014. Public Health England and UCL Institute of Health Equity, London, UK.

Rawls, J. (1985) Justice as fairness: Political not metaphysical. Philosophy and Public Affairs 14(3): 223-251.

Rosenow, J., Platt, R. and Flanagan, B. (2013) Fuel poverty and energy efficiency obligations - A critical assessment of the supplier obligation in the UK. Energy Policy 62: 1194-1203.

Sayer, A. (2011) Habitus, work and contributive justice. Sociology 45(1): 7-21.

Schlosberg, D. (2003) The Justice of Environmental Justice: Reconciling Equity, Recognition, and Participation in a Political Movement. In: Light, A. and de-Shalit, A (Eds) Moral and Political Reasoning in Environmental Practice. MIT Press, Cambridge, USA.

Schlosberg, D. (2007) Defining Environmental Justice: Theories, Movements and Nature. Oxford University Press, Oxford, UK.

Schot, J. and Steinmuller, E.W. (2016) Framing Innovation Policy for Transformative Change: Innovation Policy 3.0. Science and Policy Research Unit, University of Sussex, Brighton, UK. 
Scottish Government (2018) High Quality Sustainable Homes: Safe. Available at: www. gov.scot/About/Performance/scotPerforms/partnerstories/HARO/Indicators/Highquality-sustainable\#A1.

Sidortsov, R. and Sovacool, B.K. (2015) Left out in the cold: Energy justice and Arctic energy research. Journal of Environmental Studies and Sciences 5: 302-307.

Snell, C.J., Bevan, M. and Thomson, H. (2015) Justice, fuel poverty and disabled people in England. Energy Research and Social Science 10: 123-132.

Sorrell, S. (2015) Reducing energy demand: A review of issues, challenges and approaches. Renewable and Sustainable Energy Reviews 47: 74-82.

Sovacool, B.K. (2015) Fuel poverty, affordability, and energy justice in England: Policy insights from the Warm Front Program. Energy 93(1): 361-371.

Sovacool, B.K. and Dworkin, M.H. (2015) Energy justice: Conceptual insights and practical applications. Applied Energy 142: 435-444.

Sovacool, B.K., Heffron, R.J., McCauley, D. and Goldthau, A. (2016) Energy decisions reframed as justice and ethical concerns. Nature Energy 1: 16-24.

Sovacool, B.K., Kivimaa, P., Hielscher, S. and Jenkins, K. (2017) Vulnerability and resistance in the United Kingdom's smart meter transition. Energy Policy 109: 767-781.

Swilling, M. and Annecke, E. (2012) Just Transitions: Explorations of Sustainability in an Unfair World. UCT Press, South Africa.

Sze, J. and London, J.K. (2008) Environmental justice at a crossroads. Sociology Compass 2(4): 1331-1354.

Tebo, P.V. (2005) Building business value through sustainable growth. ResearchTechnology Management 48(5): 28-32.

Thomson, H. and Snell, C. (2013) Quantifying the prevalence of fuel poverty across the European Union. Energy Policy 52: 563-572.

Thomson, H., Snell, C.J. and Bouzarovski, S. (2017a) Health, well-being and energy poverty in Europe: A comparative study of 32 European countries. International Journal of Environmental Research and Public Health 14(6): 1-17.

Thomson, H., Bouzarovski, S. and Snell, C. (2017b) Rethinking the measurement of energy poverty in Europe: A critical analysis of indicators and data. Indoor and Build Environment 26(7): 879-901.

Todd, H. and Zografos. C. (2005) Justice for the environment: Developing a set of indicators of environmental justice for Scotland. Environmental Values 14(4): 483-501.

Viggers, H., Howden-Chapman, P., Ingham, T., Chapman, R., Pene, G., Davies, C., Currie, A., Pierse, N., Wilson, H., Zhang, J., Baker, M. and Crane, J. (2013) Warm homes for older people: Aims and methods of a randomised community-based trial for people with COPD. BMC Public Health 13: 176. DOI: 10.1186/1471-2458-13-176.

Walker, G. (2009) Beyond distribution and proximity: Exploring the multiple spatialities of environmental justice. Antipode 41(4): 614-636.

Walker, G. (2012) Environmental Justice: Concepts, Evidence and Politics. Routledge, London, UK.

Walker, G. and Bulkeley, H. (2006) Geographies of environmental justice. Geoforum 37(5): 655-659.

Walker, G. and Day, R. (2012) Fuel poverty as injustice: Integrating distribution, recognition and procedure in the struggle for affordable warmth. Energy Policy 49: 69-75.

Walker, G. and Devine-Wright, P. (2008) Community renewable energy: what should it mean?. Energy Policy 36(2): 497-500.

Welsh Government (2018) Fuel Poverty. Available at: https://gov.wales/topics/environ mentcountryside/energy/fuelpoverty/?lang=en. 


\section{Kirsten E.H. Jenkins and Mari Martiskainen}

White, V., Hinton, T., Bridgeman, T. and Preston, I. (2014) Meeting the Proposed Fuel Poverty Targets: Modelling the Implications of the Proposed Fuel Poverty Targets using the National Household Model. Centre for Sustainable Energy Report for the Committee on Climate Change, London, UK. Available at: www.theccc.org.uk/wpcontent/uploads/2014/11/CCC_ModellingProposedFuelPovertyTargets_FinalReport_ Nov2014.pdf.

Wilhite, H., Shove, E., Lutzenhiser, L. and Kempton, W. (2000) The Legacy of Twenty Years of Energy Demand Management: We Know More about Individual Behaviour but Next to Nothing about Demand. In: Jochem, E., Sathaye, J. and Bouille, D. (Eds) Society, Behaviour and Climate Change Mitigation. Kluwer Academic Publishers, Springer, USA. 